\title{
POST-DISASTER CITY RECONSTRUCTION EFFORTS AND FISHING VILLAGES TRANSFORMATION: OVER TSUNAMI DISASTER HERITAGES
}

\author{
Nao Sakaguchi \\ JSPS, Research Fellowships for Young Scientists (DC2); Graduate School of Arts and Letters \\ Tohoku University, Aoba-ku, Kawauchi27-1, Sendai, Japan.
}

E-mail: nao.pikapika.1070@gmail.com

Citation: Nao, S. 2019. Post-Disaster City Reconstruction Efforts and Fishing Villages Transformation: Over Tsunami Disaster Heritages. Japan. J. Asian Rur. Stud. 3(2): 208-220

\begin{abstract}
The objective of this study is to clarify significance and the value of the disaster remains for suffering residents from social structure. I adopt Yoshikawa's notion (2007) of postdisaster phases which is based on the analysis by Barton (1969); emergency phase $\rightarrow$ temporary phase $\rightarrow$ recovery and reconstruction phase $\rightarrow$ prevention phase. The study was conducted at AK district in Otsuchi Town, Iwate Prefecture. The data collection methods used were ethnography primarily participation observation and interviews. Participation observation was performed at the district meetings, board member meetings of various resident organizations, and community events held in the district. Interview sessions were conducted to obtain detailed responses from interviewees. The target were 50 people from the community including residents and residents directly affected by tsunami. The interview sessions were held from January 2014 to December 2017. In addition, I collected and referenced materials provided by the town council, documents on regional history, and fishery-related materials. After the disaster of 3.11, opposing opinions regarding tsunami remains became evident between community-based organizations, one of which is the management body of the community historically and the other is a newly emerged group after the disaster through a new leadership. Of these, community-based organization which is a newly emerged group insisted requiem. However, the women's association was made the purpose which uses the disaster remains as tourist attractions and produced the employment, not requiem. Through this opposition, the unique structure of the fishing village in AK district was revealed.
\end{abstract}

Keywords: Disaster Heritage; Fishing Villages; Otsuchi-Town; Tsunami disaster; Women's Association

\section{Introduction}

Most disaster heritage, defined as "something related to the memory of the tsunami", In Japan before 2011 was artifacts such as memorial monuments and tombstones. The word "disaster" remains to become popular with Japan after the announcement in November 2013 that the national government would bear the initial cost pertaining to preserving tsunami-damaged buildings. This announcement initiated many discussions on the possibility of preserving disaster reminds as tsunami heritage. However, in afflicted areas, infrastructure development was promoted by administrative top-down reconstruction planning. Furthermore, many of the / many of these damaged buildings had been dismantled without discussions of / about / on residents due to the approaching 
deadline for the fund application (Shinichi, 2014). In Japan, since the Great Hanshin Awaji Earthquake in 1995, research on residents ' participation in town reconstruction has accumulated (Urano et al . 2007). However, in many areas, the town reconstruction process has continued without discussion between residents and the government.

Previous studies on Japanese tsunami disaster remains have not paid much attention to the logic of community residents. If there is, the focus of discussion was mainly on preservation or dismantling of damaged structures for the purpose limited to disastersite sightseeing or requiem (Ishihara, 2017). In community-based reconstruction in Japan, the administrative leadership deprives the autonomy of communities.

In the Japanese study to back up disaster revitalization in the long term, it becomes clear in a community that a local resident's tissue such as neighborhood associations showed the leadership (Suzuki, 1998; Matsui 2008). The case is reported to which the resident organization of existing organizations played a role in advancing revitalization after disaster actually (Oohori, 2013).

In the revitalization process after the Great East Japan earthquake, $81.4 \%$ of the affected areas, existing residents organizations have filled in the function of establishing consensus in the reconstruction of the community. In addition, Ali, et al. (2019) illustrates a case how was the government-led local community's disaster management (CBDM) functioned effectively to provide a social system necessary in the aftermath of a disaster. Such the existing resident's organization has the base which formed a norm of the local community and the cooperation before the disaster. So its function is effective to residents planning for agreement in an independent way in privatization.

On the other hand, when a new local community led by a new leader emerges in an emergency, it shakes up the community. Previous research on the revitalization process in town planning focused on the formation of consensus by resident organizations and the unique characteristics of actions that encourage residents' participation (Dynes and Quarantelli, 1968). According to Kobayashi (2014, 2015), based on the case of the Great East Japan earthquake, a "Community-Based Organization in disaster revitalization" is characterized by (1) adjustment of the varying opinions among affected residents as well as between residents and the government, (2) operation limited to initial phase of post-disaster, and (3) distinction from pre-existing resident organizations such as neighborhood associations ("Chonai-kai"). In a natural disaster, residents put aside small daily quarrels among them. In addition, residents are placed in a "disaster utopia" (Solnit, 2009) or an "emergency social system" (Noda, 1997), where a sense of unity with the community of residents is produced. In such an environment, "community-based organizations in disaster revitalization" can facilitate the formation of consensus among residents and proceed quickly.

A common point of the existing resident organization and the community-based organizations in disaster revitalization is to function for the purpose of disaster revitalization quickly and independently. On the other hand, I think that these 2 organization are different in the ways of thinking which are formed as result of managing the community before disaster. The previous study refers to the function of these two organizations in the disaster revitalization process. However, these studies do not make them compare a function of two organizations in the disaster revitalization and not clarify sense of values and ways of thinking for the local community which become clear through the conflict. In addition, social structures of pre-tsunami community and 
background of each member of organizations remain unclear. It is necessary to explore ways for community reconstruction while considering these realities. As a result, the argument over tsunami remains superficial and the logic of residents who have lived in the area accepting multiple risks is neglected. In this report, I clarify the nature of a "community-based organization in disaster revitalization" and existing will residents organization, which has become apparent in disaster districts. Furthermore, I give light on the specific structure of a fishing village of the afficted district through conflicts between these community organizations.

\section{Methods}

According to Barton (1969), disaster-afflicted communities experience collective stress, which happens to the people when expected daily-needs of community members are not met through the social system. The idea of collective stress is a fundamental sociological perspective of long-term disasters such as the Great East Japan Earthquake. In this report, I adopt Yoshikawa's notion (2007) of post-disaster phases which is based on the analysis by Barton (1969); emergency phase $\rightarrow$ temporary phase $\rightarrow$ recovery and reconstruction phase $\rightarrow$ prevention phase. The data collection methods used were ethnography primarily participation observation and interviews. Participation observation was performed at the district meetings, board member meetings of various resident organizations, and community events held in the district. Interview sessions were conducted to obtain detailed responses from interviewees. The target was 50 people from the community including residents and residents directly affected by the tsunami. The interview sessions were held from January 2014 to December 2017. In addition, I collected and reference materials provided by the town council, documents on regional history, and fishery-related materials.

\section{Results and Discussion}

\subsection{Outline of the case study district}

The target area of this research, namely AK district in Otsuchi Town, Iwate Prefecture, attracted attention worldwide after the tsunami for the impressive scene which a sightseeing ship landed on top of a guesthouse. The ship was dismantled two months after the disaster by the adjacent administration who was the owner and considered it dangerous to its surrounding. Residents of the AK district hoped to restore the sightseeing ship to its original state six months after the disaster. They reached a consensus that the ship should remain as disaster remains. 


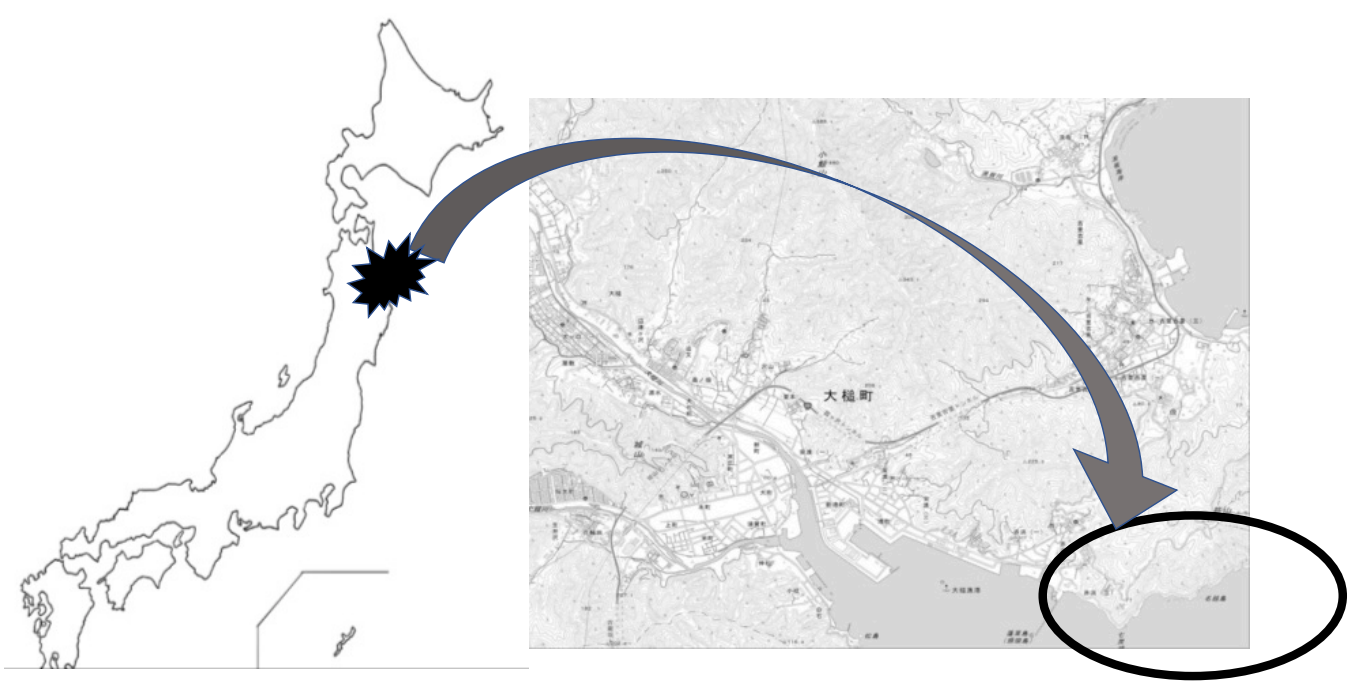

Figure 1. Position of the AK district in Otsuchi-Town, Iwate Prefecture

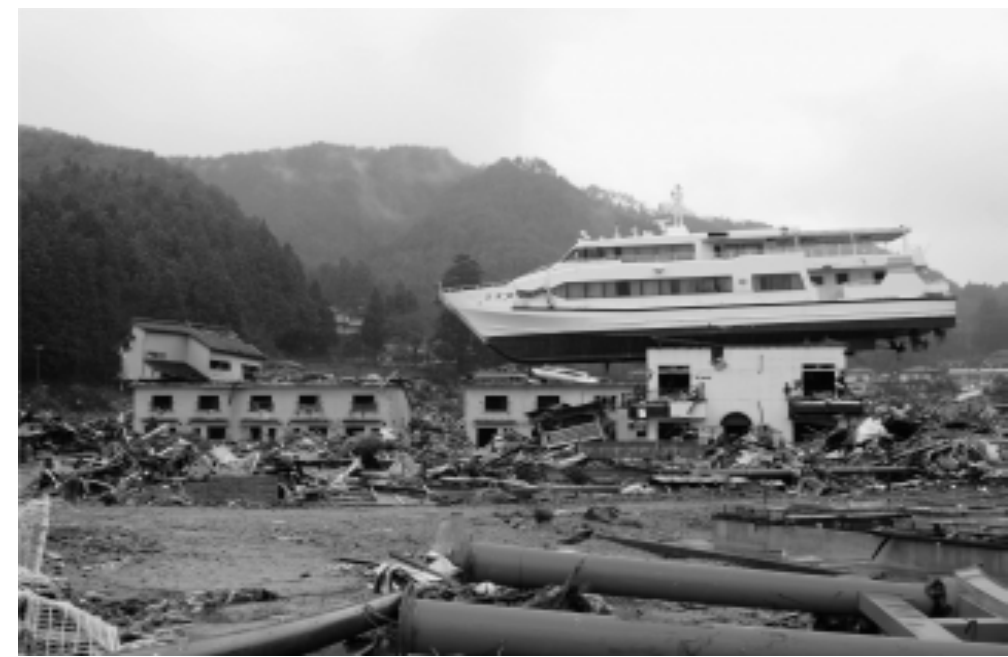

Figure 2. Sightseeing ship washed ashore on a guesthouse by the tsunami

The AK district is located on the edge of the Gulf of the Rias coastline, where two large rivers flow in from the mountain. The town has developed thanks to its rich fishing grounds. The AK district is geographically isolated, but there has been continuous interaction with people outside by the sea. The characteristic of the deep gulf in AK district catered to develop shipyards and dockyards in the region and that facilitated frequent exchanges with local and out-of-town fishermen. The modernization of fishing ports started from 1947 enabled deep-sea fishing in the area and it remained popular until the 1980s. However, the oil shock, which delivered a worldwide blow in the 1970s, and the establishment of the 200 nautical mile system forced the 
transformation of the large-scale deep-sea fishing method and the number of fishermen declined subsequently. Consequently, the population and number of households in the area continued to decrease with its max of 1,325 people in 1985 (Table 1). Many fishing villages nationwide have converted to aquaculture in accordance with the national fisheries policy. However, contrary to the nationwide movement, the AK district is a distinctive area where inshore fisheries have remained popular even after 1980 (Table 2). The population before the disaster in the area was 938 people in 371 households. In total, 95 people in the district died in the Great East Japan Earthquake $(10.2 \%$ of the population). Furthermore, $70 \%$ of households lost their houses.

Table 1. The changes in the number and percentage of population, workers and households of AK district ${ }^{\mathrm{a}}$

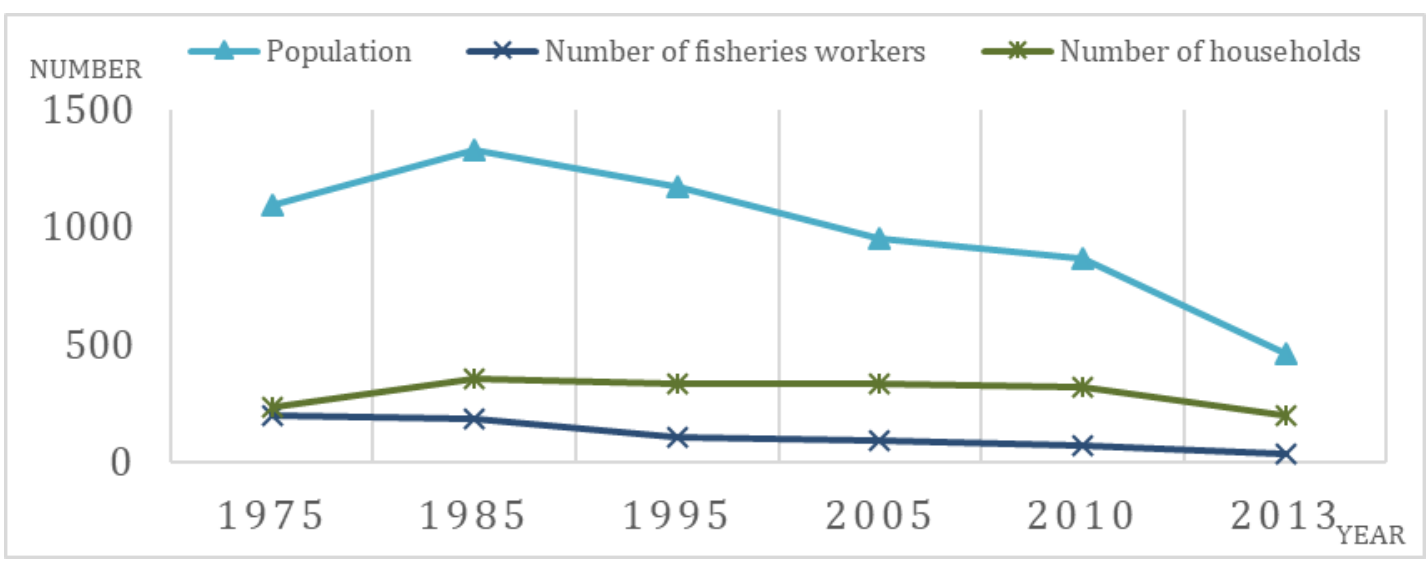

Source: Statistical Survey Department, Statistics Bureau, Ministry of Internal Affairs and Communications.

Table 2. Transformation of fisheries workers and comparison ${ }^{b}$

\begin{tabular}{|c|c|c|c|c|c|}
\hline & (year) & $\begin{array}{c}\text { Total } \\
\text { Fisheries } \\
\text { workers }\end{array}$ & $\begin{array}{l}\text { aquaculture } \\
\text { (number of } \\
\text { fisheries } \\
\text { worker/rate) }\end{array}$ & $\begin{array}{c}\text { Inshore fishery } \\
\text { (number of } \\
\text { fisheries } \\
\text { worker/rate) }\end{array}$ & $\begin{array}{c}\text { Pelagic fishery } \\
\text { (number of } \\
\text { fisheries } \\
\text { worker/rate) }\end{array}$ \\
\hline \multirow[t]{3}{*}{ Ak district } & 1988 & 25 & 11 (44.00\%) & 11 (44.00\%) & $3(12.00 \%)$ \\
\hline & 1998 & 35 & $9(25.71 \%)$ & $20 \quad(57.14 \%)$ & $6(17.15 \%)$ \\
\hline & 2008 & 33 & $7 \quad(21.21 \%)$ & 22 (66.67\%) & $4 \quad(12.12 \%)$ \\
\hline \multirow[t]{3}{*}{ Neighboring district } & 1988 & 88 & $16(18.19 \%)$ & $62(70.45 \%)$ & $10(11.36 \%)$ \\
\hline & 1998 & 61 & $41 \quad(67.22 \%)$ & $10(16.39 \%)$ & $10 \quad(16.39 \%)$ \\
\hline & 2008 & 42 & $22(52.38 \%)$ & $18(42.84 \%)$ & $2(4.78 \%)$ \\
\hline \multicolumn{2}{|c|}{$\begin{array}{r}\text { Two prefectures affected } \\
2008\end{array}$} & 9319 & $4696 \quad(50.39 \%)$ & $4373(46.93 \%)$ & $240 \quad(2.58 \%)$ \\
\hline
\end{tabular}

Source: The Census of fisheries

\subsection{Community organization in the AK district before the disaster (preventive phase)}

The AK district did not have a neighborhood association (like "Chonai-kai") before the disaster. The reason is that most households belonged to the AK-district fishermen's cooperative association, which served a consensus building function. The district-based 
fishermen's cooperative associations merged into a single town-wide organization in 1971, making it difficult to form a consensus in the district. Following this, what emerged as an alternative organization in building the consensus of residents was a group of representatives at local Shinto shrines ("Soudai-kai"). The representative meeting consisted of leaders of the fishery such as ship-owners and chief fishermen. However, as the number of fishermen decreased, the district residents had a diverse array of jobs. Therefore, the representative meeting did not serve the function of building consensus among residents. However, only the representatives were able to participate in the meeting and decide on community matters. In the AK district, the relation between the head family and branch family was not strong, and there was no "Keiyaku-kou", which is characteristic of the Tohoku coastal area. During the 30 years before the disaster, the $\mathrm{AK}$ district lacked an association that functioned to form a consensus among residents. The earthquake occurred around when some residents were considering initiating a residents' association.

Table 3. Transformation of district management organization.

\begin{tabular}{cc}
\hline Until about 1975 & ost households belonging \\
\hline Fishermen's cooperative association & $\begin{array}{c}\text { Consensus formation for some } \\
\text { residents only }\end{array}$ \\
\hline Representative meeting of the fishery "Soudai-kai & $\begin{array}{c}\text { Many members of the group } \\
\text { had not participated in } \\
\text { community activity }\end{array}$ \\
\hline $\begin{array}{c}\text { Eugust 2011-2013 } \\
\text { Establishment of the consideration meeting for the } \\
\text { reconstruction of the AK district }\end{array}$ & \begin{tabular}{c} 
com \\
\hline
\end{tabular}
\end{tabular}

\subsection{Life in the evacuation shelter (March 11 to August 2011 : The emergency and temporary phase)}

The aftermath of the disaster, the government of Otsuchi no longer functioned as the mayor and 40 government officials had died and it was the only municipality unable to propose the reconstruction plan. However, because of this situation, many residents of Otsuchi proactively became involved in the reconstruction process (Takezawa, 2013).

Life in the evacuation shelter in the AK district, wherein hundreds of people lived, was led by 13 organized groups, such as a group responsible for managing relief supplies and self-security. This system was organized by a pre-existing local voluntary organization for disaster prevention. Every morning at 8:00 am, the leaders of each group held a meeting to share information. One characteristic of life in the AK district shelter was that evacuees did not put up the cardboard partitions between spaces allocated for each household for privacy7. The unity of residents strengthened through sharing life in this way. Reflecting on their lives in the evacuation shelter, many residents told me, "We were united for a few months after the disaster, which had been unthinkable before the earthquake".

Members of the local voluntary organization for disaster prevention negotiated with more than 100 landowners to ensure that evacuees would not be dispersed when moving into the temporary housing. As a result, $90 \%$ of the district residents who lost their homes entered temporary housing in the AK district. 


\subsection{Establishment of the consideration meeting for the reconstruction of the AK} district August 2011 to December 2011: The recovery and reconstruction phase)

Initially, residents expected the representative meeting ("Soudai-kai") to take leadership in shelter life and town planning for reconstruction. However, members of the "Soudai-kai" did not lose their families or homes in the disaster, and did not participate in the management of the evacuation shelter. For this reason, the residents were disappointed with the members of the "Soudai-kai". Consequently, residents met to consider the possibility of acting autonomously to ensure the reconstruction of the AK district (hereafter referred to as "consideration meeting").

The members consisted of 24 men and 4 women aged from their 30 s to 70 s including eight fishermen. Members were recruited by Mr. A, the chairman of the consideration meeting. Member selection was not based on previous involvement in local events and management before the disaster, but on the trust of other residents in the management of the evacuation shelter.

To convince the government of the reconstruction plan devised by the meeting members, the seven sessions of the steering committee were held from August 2011 in two months. The center of the discussion was the restoration of the ship landed on a guesthouse. The core idea of this was that the restored ship and inn would serve as tsunami disaster heritage and its impressive sight would attract people from all over the world to the AK district. One interviewee responded, "Thanks to Hamayuri (the name of ship), I felt openness in the district and fulfilled." (February 20, 2014: Interview with Mr. Q).

In addition, charmed by the scene, Mr. AA, an outside supporter, moved to the AK district proposing a plan to build a memorial park surrounding the disaster remains8. The consideration meeting regarded $\mathrm{Mr}$. AA as a member for his provision and knowledge in reconstruction. Mr. AA highlighted the possible economic impact of "sightseeing and job creation" by restoring the ship as a tsunami heritage. In contrast, other members of the consideration meeting expressed mixed feelings towards the idea that the victims of the disaster would become a "sightseeing" site. They simply wanted a site to become where never-ending offerings of incense sticks keep memories (Higashino, 2012). The claims of the two were obviously contradictory. Under Mr. A's policy to "move forward the discussion no matter what for the speedy reconstruction", the AK district reconstruction plan was drawn out based on the proposal submitted by Mr. AA with the purpose of the tsunami heritage being "requiem and education for the future generations". The proposal was a compromise of two incompatible ideas.

On October 2011, the consideration meeting opened a general meeting for all the community members to build consensus on the proposed 12-item plan, including a proposal to reject government-led reconstruction of the large seawall. Following this, the government accepted the proposed plan. Thus, the AK district became the frontrunner of reconstruction.

\subsection{Deterioration of the consideration meeting (2013: The preventive phase)}

According to the consideration meeting, the first priority of reconstruction was given to the rebuilding of houses, and naturally, the restoration of the ship was a lower priority. However, in 2012, a group surfaced requesting the restoration of the vessel be progressed in parallel with the rebuilding of housing. The group mainly consisted of 
members of the women's association in AK district9. The women's association had actively set up a campaign to collect signatures in and out of the community and spoke openly about the restoration at meetings. The purpose of the restoration for the women's group was "sightseeing and job creation" rather than "requiem and education", which derived from the women's realistic sense of life and desire for the regeneration of the district. However, members of the consideration meeting voiced their concerns towards them saying, "(the women's association) create too much noise. We have built consensus at the residents' general meeting. We have to be united. I am not against their idea, but the priority is different" (January 22, 2014: Interview with Mr. D). The women's association continued to propagate restoration to the point that conflict between the women's association and the consideration meeting were palpable.

In the consideration meeting, disputes between Mr. A and Mrs. R, the chairperson of the women's association, became frequent and discussions for reconstruction were repeatedly interrupted. Finally, Mr. A excluded Mrs. R and Mr. AA from the discussion forum. Some members boycotted the discussion to protest this action. In addition, Mr. A's autocratic actions such as not disclosing government information to residents were revealed and the government was requested to deal with the situation. The government intervened from September 2013. The residents' association was launched in April 2015 and its members were mainly the people from the local voluntary organization for disaster prevention

\section{Consideration}

\subsection{The consideration meeting: Functions as a community-based organization in disaster revitalization}

The consideration meeting functioned for a year and a half from the beginning of August 2011 to 2013. Many members of the meeting had not participated in community activities before the disaster, thus, the discussions inevitably did not reflect local norms and district structures before the disaster. As such, "it was a place where we could talk about dreams and the regeneration of a new district. There was a sense of euphoria" (August 8, 2014: Interview with Mr. K). The meeting created a place where norms before the disaster disappeared and any opinions could be freely discussed. This represents the definition of a disaster utopia.

On the other hand, the success of the meeting depended on the strong leadership of Mr. A, who was able to adjust a variety of opinions from residents during the emergency phase. To promote reconstruction, Mr. A decisively added out of town supporters as its members and drafted a community-led reconstruction plan. Mr. A was a former government official and inevitably his skills and knowledge on negotiation with the local government influenced his success as a leader. His father and grandfather were fishermen. His uncle owned a deep-sea fishing ship and was the chairman of the pre-tsunami fishermen's cooperative association about 30 years ago. Mr. A was not involved in community activities before the disaster. He lost three family members and his house in the disaster. He became actively involved in the operation of the evacuation center, such as handling and managing of volunteer groups from outside. During the evacuation shelter period, Mr. A worked with residents of the same generation (in their $60 \mathrm{~s}$ ) and tried to set up an organization to encourage autonomy in the reconstruction of 
the district. Members described Mr. A as follows; "He did not say anything, but he was always thinking about the district although he lost his mother, wife, and grandchild in the tsunami. He was a doer. That's why we trusted him to have final words in meetings." (January 22, 2014: Interview with Mr. D).

"It is not always necessary to reach a consensus. We decided to advance quickly. We couldn't have come this far without him" (August 4, 2014: Interview with Mrs. S and Mr. H).

When I interviewed 20 members of the consideration meeting, everyone affirmed the strong leadership provided by Mr. A by saying it "was necessary at that time." Why did the residents want strong leadership? The AK area has a relatively high percentage of fishermen with fishing boats. The fishing boat fishery is by the lead boatman and the hierarchy of following boats is clear. Therefore, there was no resistance in the AK area to actively embrace the character who demonstrated strong leadership. Through their work, the resident understood the necessity of strong leadership in the face of an emergency. Furthermore, his preparedness for reconstruction persuaded many residents. One resident said, "I wanted to return to the place I had lived before the disaster because there were no building restrictions at that time. However, Mr. A said, 'I throw away the land, so you throw it away, too. Everyone is moving'.

From the above, based on the attributes and internal structure of the members, the function of a community-based organization in disaster revitalization is clearly temporary. Community-based organizations in disaster revitalization serve the function of encouraging reconstruction. Residents accepted Mr. A's strong leadership and autocratic actions expecting reconstruction to proceed, as the group served the temporary function. Residents had said about the AK district before the disaster as "a district unable to form consensus". Therefore, residents realized that it was essential that local resident unite and cooperate to overcome the emergency, and they craved an organization to lead them. Therefore, the community-based organization in disaster revitalization emerged and functioned in AK district.

\subsection{Structure of AK district identified through the internal conflict}

The women's association had the longest history in the district, sustaining the regional way of life including the values and norms before the disaster. Interviews conducted with ten members of the women's association revealed, "After the disaster, I was surprised to find out that people who had not been involved in the district management were gathering and thinking about rebuilding the district" (October 17, 2017: Interview with Mr. RC). There was no member of Soudai-kai in the consideration meeting. In addition, many people involved in the local organizations before the disaster did not participate in the consideration meeting for reasons of poor health and so on.

Why did the women's association object to membership of the consideration meeting and the way they proceed with the discussion for reconstruction? An analysis of the internal structure of the women's association indicated that most members were 60 years of age and over, and their husbands were deep-sea fishermen. However, around half of the members were widowed from sea accidents. The members of the women's association had been working hard to make living, and consequently had pushed the regional economy forward. In addition, the generation of most members was used to helping each other within the community for their daily lives. Therefore, the women's association has always advocated a regional revitalization before responding to 
individual needs. That was the reason why they objected the decision of the consideration meeting to make the rebuilding of houses a top priority. The women's association focused on potential economic activities the tsunami heritage could bring to the region, and therefore demanded the purpose of tsunami heritage being "sightseeing and job creation" rather than "requiem and education".

Table 3. List of members of the consideration meeting for the reconstruction of $\mathrm{AK}$ District

\begin{tabular}{|c|c|c|c|c|c|c|c|c|c|}
\hline & Post & Sex & Age & Hom etow $n$ & 0 ccupation & Local participation & $\begin{array}{l}\text { Fishery related } \\
\text { person }\end{array}$ & D am ag ing & Shelter life \\
\hline A & Chairperson & M & $60 \mathrm{~s}$ & AK & $\begin{array}{l}\text { Governm ent } \\
\text { official } \\
\text { (retirem ent) }\end{array}$ & no & $\begin{array}{l}\text { (Re lative } / 0 \text { w ner: } \\
\text { retirem ent) }\end{array}$ & $\begin{array}{l}\text { Lose } 3 \text { fam ilies and } \\
\text { hom e }\end{array}$ & No:0 peration \\
\hline B & V ice-cha irperson & M & $60 \mathrm{~s}$ & AK & Self em p loyed & no & $x$ & $\begin{array}{l}\text { Lose fam ilies and } \\
\text { hom e }\end{array}$ & Yes:0peration \\
\hline $\mathrm{C}$ & Vice-cha irperson & M & $40 \mathrm{~s}$ & AK & Fisherm an & no & 0 & Safety & No \\
\hline $\mathrm{D}$ & Secretary general & M & $50 \mathrm{~s}$ & The tow $n$ & Self em p loyed & no & $x$ & Lose hom e & Yes:0peration \\
\hline E & Secretariat & W & $40 \mathrm{~s}$ & AK & $F$ ish ing industry & yno & $\begin{array}{l}O(\text { Owner: } \\
\text { retirem ent) }\end{array}$ & Lose hom e & Yes \\
\hline $\mathrm{F}$ & & M & $60 \mathrm{~s}$ & AK & $\begin{array}{l}\text { Governm ent } \\
\text { office } \\
\text { (retirem ent) }\end{array}$ & D irector citizen & $x$ & Lose hom e & Yes:0peration \\
\hline G & & M & $60 \mathrm{~s}$ & AK & $\begin{array}{l}0 \text { ffice w orker } \\
\text { (retirem ent) }\end{array}$ & $\begin{array}{l}\text { D irector citizen, } \\
\text { Voluntary } \\
\text { organ ization for } \\
\text { disaster prevention }\end{array}$ & $x$ & Lose hom e & Yes:Reader \\
\hline $\mathrm{H}$ & & W & $40 \mathrm{~s}$ & AK & Housew ife & PTA & $x$ & $\begin{array}{l}\text { Lose fam ilies and } \\
\text { hom e }\end{array}$ & Yes:0peration \\
\hline I & & M & $30 \mathrm{~s}$ & AK & F isherm an & no & 0 & Lose hom e & No \\
\hline $\mathrm{J}$ & & M & $40 \mathrm{~s}$ & AK & 0 ffice w orker & no & $x$ & Lose hom e & Yes:0 peration \\
\hline K & & M & $40 \mathrm{~s}$ & The tow $n$ & 0 ffice w orker & PTA & $x$ & Lose hom e & Yes:0peration \\
\hline L & & W & $50 \mathrm{~s}$ & $?$ & Housew ife & no & $x$ & Lose hom e & No \\
\hline M & & M & $50 \mathrm{~s}$ & AK & F ishem an & F irefighting team & 0 & Safety & No \\
\hline $\mathrm{N}$ & & M & $50 \mathrm{~s}$ & $?$ & 0 ffice w orker & no & $?$ & Safety & No \\
\hline $\mathrm{O}$ & & M & $50 \mathrm{~s}$ & Ak & F isherm an & no & $O$ (Owner) & Lose hom e & Yes \\
\hline$P$ & & M & $60 \mathrm{~s}$ & The prefecture & Carpenter & $\begin{array}{l}\text { Voluntary } \\
\text { organ ization for } \\
\text { disaster prevention }\end{array}$ & $x$ & Lose hom e & Yes:0peration \\
\hline Q & & M & $70 \mathrm{~s}$ & $\begin{array}{l}\text { Outside the } \\
\text { prefecture }\end{array}$ & $\begin{array}{l}0 \text { ffice w orker } \\
\text { (retirem ent) }\end{array}$ & D irector citizen & $x$ & Safety & No \\
\hline $\mathrm{R}$ & & W & $60 \mathrm{~s}$ & The prefecture & $\begin{array}{l}\text { Tourist trade } \\
\text { (retirem ent) }\end{array}$ & Wom ans association & $\begin{array}{l}\text { O(Husband/ } \\
\text { crew m em ber }\end{array}$ & Lose hom e & Yes:0peration \\
\hline S & & M & $60 \mathrm{~s}$ & AK & $\begin{array}{l}0 \text { ffice w orker } \\
\text { (retirem ent) }\end{array}$ & D irector citizen & $\begin{array}{l}\text { O(Father/crew } \\
\text { m em ber) }\end{array}$ & Lose hom e & Yes:0peration \\
\hline $\mathrm{T}$ & & M & $60 \mathrm{~s}$ & AK & F ish ing industry & y no & $x$ & Safety & No \\
\hline $\mathrm{U}$ & & M & $60 \mathrm{~s}$ & AK & F isherm an & no & 0 & Lose hom e & No \\
\hline V & & M & $60 \mathrm{~s}$ & AK & Fisherm an & no & 0 & Safety & No \\
\hline W & & M & $60 \mathrm{~s}$ & AK & Carpenter & no & $?$ & $\begin{array}{l}\text { Lose fam ilies and } \\
\text { hom e }\end{array}$ & Yes:0peration \\
\hline $\mathrm{x}$ & & M & $70 \mathrm{~s}$ & AK & Self em p loyed & no & 0 & Lose hom e & Yes \\
\hline Y & & M & $50 \mathrm{~s}$ & AK & F isherm an & no & 0 & Safety & No \\
\hline Z & & M & $60 \mathrm{~s}$ & AK & F isherm an & no & 0 & Safety & No \\
\hline A A & Adviser & M & $60 \mathrm{~s}$ & $\begin{array}{l}\text { Outside the } \\
\text { prefecture }\end{array}$ & Artist & & & - & \\
\hline $\mathrm{AB}$ & Adviser & M & $60 \mathrm{~s}$ & The tow $n$ & Tow n councillor & & & - & \\
\hline
\end{tabular}

The division of labor by gender was evident in regional management: Men worked at the sea and competed against other fishermen on a daily basis, while women collaborated on land and created a mutual livelihood. Therefore, the priority of the reconstruction for the member of the women's association might have been the restoration and the preservation of the ship as the regional revival. 
In the area struck by the Great East Japan Earthquake and tsunami, many residents had succumbed to previous tsunamis and fishing accidents in the past. Therefore, the district had the wisdom and cultural sensitivity to accept any disaster situations (Kanebishi, 2013; Sakaguchi, 2017). The "requiem and education" was conceptualized by residents as a way to live through hardship, not as an appeal of hardship, as well as highlighting the importance of sharing the knowledge of disaster for future generations to avoid the same mistake to be made. Based on this background, the idea of the "requiem and education" for tsunami heritage was widely accepted throughout areas affected by the Great East Japan Earthquake and tsunami. Although members of the women's association understood the idea, they also take pride in protecting and managing the community with collaboration with other women while men were absent at the sea. The women's association members judged that it was important to use disaster remains as tourist resources to play area operation like the area where there were bustling with fishing formerly based on done their experiences. In this way, their differences from the community-based organization in disaster revitalization were brought to light and the logic of the women's association became clear

\section{Conclusion}

As a result of conflict with a community-based organization in disaster revitalization regard in the meaning of the Great East Japan Earthquake and disaster remains, the logic of women involved in land activities of deep-sea and inshore fishery became prominent. Here, two opposing logics are evident, one focusing on the healing of survivors while the other focusing on a strategic vision for future living. A point of view called the tradition for disaster prevention was generally regarded as important, and the disaster remains have been considered to be a social idea. Tsunami remains have been socially understood and accepted as a tool for future disaster prevention and preparation. This paper revealed a perspective of residents who have lived through the high-risk lifestyle of fishermen for generations and thus having close contact with death in daily living. Their position on how to "utilize" the tsunami remains is based on these real-life experiences and mindset.

From this research, I would like to make the following two proposals. First, it is necessary to think about the positioning of community-based organizations in disaster revitalization. A community-based organization in disaster revitalization is a special temporary structure and is different from the traditional community structure. In an emergency situation, a few contrastive social structures, which are unique to the region, may possibly surface. Only after recognizing this potential will it be possible to identify points of contention. Second, it is about the unit for realizing the residents-based reconstruction planning. An administration pushes a top-down and uniformed reconstruction framework for the sake of budget enforcement within the time limit. However, in the Great East Japan Earthquake and tsunami, the values and culture of the inhabitants shared by the fishing village became apparent. Of course, confrontations by residents happen. Nevertheless, the importance of making a community-centered reconstruction plan for each region became apparent in the case of the great East Japan earthquake. Understanding the needs of the local resident through a community-led reconstruction plan could reduce the time and expense for the reconstruction in the end. 


\section{Acknowledgments}

This work was supported by JSPS KAKENHI Grant Number JP18J12564 and The Konosuke Matsushita Memorial Foundation.

\section{References}

Barton, A. H., 1969. Communities in Disaster: A Sociological Analysis of Collective Stress Situations, New York: Garden City.

Diversity Research Institute, 2015. Recovery Town Planning in Iwate, Miyagi and Fukusima: Reports of the Resident's Organization of Establishing Consensus in the Reconstruction (Japanese).

Dynes, R. R., and E. L. Quarantelli, 1968. Group Behavior Under Stress: A Required Convergence of Organizational and Collective Behavior Perspectives. Sociology and Social Research, 52(4) pp416-429.

Hamamoto, S., 2012. Tourism and Natural Disasters in Indonesia as a Measure of Social.

Higashino, M., 2012. Resident Reporter: 365 days from the disaster in Otsuchi (Japanese) (Tokyo: Iwanami syoten) pp116 [東野真和 2012 『駐在記者発 大槌町震災からの365日』岩波書店 pp116]

Ishihara, R., 2017. How to Connect Memory of Disaster: in the Preservation of the Remains of the Disaster (Japanese) The municipal problem 108(3) pp37-47 [石原凌河 2017 「災害の記憶をどうつないでいくか 災害遺構の保存をめぐって」『都市問題』108(3) pp37-47]

Kanebishi, K. ed., 2013. The Seaside Studies of the Millennium Disasters: Why Still People Live in the Sea (Japanese) (Tokyo: Seikatsusyoin) [ 金菱清編 2013 『千年災禍の海辺学 なぜそれでも人は海で暮らすのか』生活書院]

Kobayashi, H., 2014. Study on Adjustment of Opinion in Disaster Revitalization Process: The Case of Miyagino (Japanese). The annals of Japan Association for

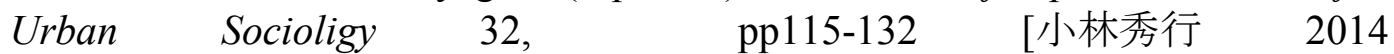
「災害復興における住民組織による調整一仙台市宮城野区の事例」『日本 都市社会学会年報』52(4) pp416-429].

Kobayashi, H., 2015. Function and Role of a Community-Based Organization in Disaster Revitalization: As a Case Study the Great East Japan Earthquake and Tsunami (Japanese). Japan association for Age-free Society 2014 reports (Tokyo: Japan association for Age-free Society secretariat), pp49-59 [小林秀行 2015 「緊急コミュニティ組織の役割と機能

東日本大震災を事例として」『シニア社会学会 災害と地域社会研究会 2014年度報告書』シニア社会学会・事務局 pp49-59].

Matsui, K., 2008. Memory of Tyuetsu Earthquake: The Bond of People and Road to Revitalization.

Koshi hall [松井克浩2008『中越地震の記憶一人の絆と復興への道』高志書院］.

Noda, T., 1997. Disaster and Social System (Japanese) (Tokyo: Kouseisya Kouseikaku). pp9-32 [野田隆 1997 『災害と社会システム』恒星社厚生閣 pp9-32]. 
Oohori, K., 2013. Study on Conditions to Satisfy both of Plan-making and Residents Participation after Disasters: The Case of Kamaishi City Annals of Regional and Community Studies, 25 pp127142 [大堀研2013「災害後の計画策定と住民参加とが両立する条件につい ての考察一岩手県釜石市の事例」『地域社会学会年報』25 pp127-142].

Rahmadhani, 2012. From the tsunami disaster area of the world to the world tsunami tourism base (Japanese) Disaster heritage and creative economy: from perspective of area informatics ed Yamamoto H and Nishi Y(Kyoto: Center for Integrated Area Studies (CIAS), Kyoto University) pp75-77

reconstruction (Japanese) Disaster Heritage and Creative Economy: From Perspective of Area Informatics ed Yamamoto H and Nishi Y(Kyoto: Center for Integrated Area Studies (CIAS), Kyoto University) pp78-83

S. Ali, M. Saleh, et al., 2019. Community Based Disaster Management: Indonesian Experience. IOP Conference Series: earth and Environmental Science Vol. 235, Conference 1.

Sakaguchi N., 2017. Earthquake reconstruction and Collective memory: The logic of residents over the height of the seawall (Japanese). Sociology study 100 pp207233 [坂口奈央 2017

「震災復興と集合的記憶 防潮堤の高さを巡る住民の論理」『社会学研究』100 pp207-233]

Shinichi S 2014 Disaster and tradition district wisdom that protects life(Japanese) (Tokyo: kokonsyoin) pp178-181. [杉本真一 2014 『災害伝承の活用 災害遺構の保存に向けて』古今書院 pp178-181]

Solnit R 2009 A Paradise Built in Hell: the extraordinary communities that arise in disaster (USA:PENGUIN BOOKS) (=2010 Takatsuki S Tokyo: Akishobo) .

Suzuki H ed 1998 Study of disaster urban: Simabara-city and Fuge-mounten Kyusyu University 鈴木広編1998『災害都市の研究一島原市と普賢岳一』九州大学出版会.

Takezawa S 2013 Live after the disaster: Record of Struggle in Kirikiri, Otsuchi and Kamaishi (Japanese) (Tokyo: Chuokoron Shinsya) pp161-173 [竹沢尚一郎 2013 『被災後を生きる 吉里吉里・大桘・釜石奮闘記』中央公論新社 pp161173].

Urano M, Ooyane J and Yoshikawa T 2007 Introduction to reconstruction community theory (Tokyo:koubun-do)

Yoshikawa T 2007 Types of restoration and reconstruction (Japanese) Introduction to reconstruction community theory (Tokyo:koubun-do) pp37-48 [吉川忠寛 2007 「復旧・復興の諸類型」浦野正樹・大矢根淳・吉川忠寛編『復興コミュニ ティ論』弘文堂 pp37-48]. 